\title{
To Remain or Not to Remain Silent: The Evolution of The Privilege against Self- incrimination Ten Years After Marttinen v. Finland
}

\author{
TUOMAS HUPLI*
}

\section{Introduction and Basic Problems}

According to the judgment of the European Court of Human Rights (ECtHR) in Marttinen v. Finland, ${ }^{1}$ a debtor has the right to remain silent in a debt enforcement enquiry given that the following conditions are met: first, that the inquiry is held concurrently with a criminal procedure; and second, that the same questions of evidence are investigated in both of the concurrent proceedings. Under these circumstances, the debtor enjoys the privilege against self-incrimination in the enforcement enquiry. The scope of this article is to examine whether the debtor has not only the right to remain silent, but also the right to give false statements.

* Professor of Procedural Law, University of Turku, Finland. Certain parts of this article were published earlier in Finnish, see Hupli, Would I lie to you? Valehtelu itsekriminointisuojan erityisongelmana in Oikeutta oikeudenkäynnistä täytäntöönpanoon. Juhlajulkaisu Tuula Linna, ed. Riekkinen (Alma Talent Oy 2017) pp. 75-87. This article includes an assessment of the case law that became available after the Finnish version was published. All web addresses last checked on 17 January 2019.

$1 \quad$ Appl. no. 19235/03, 21.4.2009.

This is an Open-access article distributed under the terms of the Creative Commons Attribution 3.0 Unported License (http://creativecommons.org/licenses/ by/3.0/), permitting all use, distribution, and reproduction in any medium, provided the original work is properly cited. 
In Marttinen v. Finland, the long tradition of the privilege against self-incrimination turned a new page. The judgment of the ECtHR in that case expresses the national tensions, but also more generally the Europe-wide values behind the problems that led to the case.

The basic problem in Marttinen v. Finland was that the debtor refused to disclose the information that was required in the debt enforcement enquiry. The refusal was grounded on the right to remain silent, as everyone has the right not to incriminate oneself while the same (alleged) facts are investigated in criminal procedure. The Government of Finland stated that there is no right to remain silent in an enforcement inquiry and that the administrative fine imposed against the applicant, Mr. Marttinen, did not violate his privilege against self-incrimination. The ECtHR, for reasons addressed in detail in this article, held a contrary view and thus found that there had been a violation of Article $6 \$$ 1 of the European Convention on Human Rights (hereinafter the Convention).

Exactly the same problem is present in many other kinds of legal proceedings when they are pending simultaneously with a criminal procedure (either in the pre-trial stage or at court). Typical examples of these are official tax audits, bankruptcies and investigations of customs duties. The preliminary power of the ECtHR's judgment in the Marttinen case is therefore remarkable.

Now, nearly a decade after the Marttinen case, it is time to analyse its aftermath. In dealing with the privilege against self-incrimination, are we any wiser than we were before the Marttinen case and the judgment given therein? If we are, how can we verify this? We can even ask how the future of the privilege against self-incrimination will look. The aim of this article is to offer a well-grounded picture of the changes that have occurred after the ECtHR's judgment in the Marttinen case and, directly or indirectly, as a result of it.

The aftermath of Marttinen v. Finland can be divided into the following sections:

- The direct impact on case law;

- The direct impact on law drafting and legislation, and;

- The indirect impact on criminal liability for false statements. ${ }^{2}$

There is no doubt that the privilege against self-incrimination protects the right to remain silent in any proceeding concurrent to simultaneous criminal investigations. Given that the privilege is limited to silence only, it actually means a duty to stay quiet (or, at least, a duty to refrain from giving false statements) in concurrent procedures. Conversely, if false statements are allowed, the privilege against self-incrimination covers much more than merely the right to remain passive and silent. In principle, the privilege

2 The aim of this article is not to produce recommendations for how to interpret the criminalisation of false statements (fraud, tax fraud, fraud by a debtor, false statements in court, etc.). Rather, false statements are to be explored only for the purpose of analysing the privilege against selfincrimination. 
includes the following alternatives: to exercise the right to remain silent or to waive that right by telling the truth or by giving a false statement.

After the introduction provided in this section, section 2 of this article will include a brief analysis of the essence and moral basis of the privilege against self-incrimination. As these concepts are fairly well-investigated in the legal literature and in the case law of many jurisdictions, the focus of section 2 is on the elements that either support or contest the right to give false statements. Sections 3 and 4 provide an analysis of the current state of the law governing the privilege against self-incrimination according to the law of Finland. The reason for choosing Finnish law as an example is that, regarding the privilege against self-incrimination, remarkable law reforms and rulings of the Supreme Court have taken place during the first decade after the Marttinen case. Altogether, the development of the privilege expresses the tensions between the public interest of finding the truth in particular cases and, on the other hand, the efforts to meet the requirements of a fair trial, as demanded by Article 6 of the Convention. ${ }^{3}$

\section{The Moral Basis of the Privilege Against Self-Incrimination}

The idea behind the adversary (accusatory) criminal procedure is that proving suspicions and charges is up to the authorities performing their assigned functions under the law. ${ }^{4}$ Hence, the duty to act belongs in the first stage to the police (preliminary investigation) and then to the prosecutor in considering and bringing charges at court. From this, it follows that the accused has no duty to contribute to the efforts to prove the charges.

At a minimum, the right not to contribute to the investigation of a self-related criminal charge means the right to remain passive. Even children watching courtroom dramas based on common law culture are familiar with the essence of Miranda rights: 'You have

3 It must be noted that the public interest in investigating the truth in official proceedings does not, in itself, violate the privilege against self-incrimination. See, for example, the ECtHR case Allen v. the United Kingdom, 10.9.2002, where the applicant made a false declaration of his assets. This constituted the crime itself (the offence itself), as there were no allegations of any earlier offence against which the applicant would have needed the protection of the privilege.

4 Much has been written on the adversary principle as one of the cornerstones of a fair criminal trial. For recent case law of the ECtHR, see e.g. Schatschaschwili v. Germany, appl. no. 9154/10, 15.12.2015, in which the court held by 9-8 votes that Article $6 \$ \$ 1$ and 3 (d) of the Convention had been violated. The adversary principle is of course one of the basic elements of the Finnish law on criminal procedure. For more on these principles, see Frände, Finsk straffprocessrätt (Edita 2009) pp. 29-32. 
the right to remain silent. ${ }^{5} \mathrm{Up}$ to this point, the content of the privilege against self-incrimination is clear: the accused has the right not to say anything. A more complicated question is whether there is some sort of obligation involved in this, i.e., a duty to refrain from giving false statements. When assessing whether the privilege against self-incrimination only means the right to remain silent or whether it implies a more extensive obligation to hold one's tongue, it would be useful to pause and consider the moral grounds for this privilege.

First, the links between the privilege and Enlightenment philosophy are obvious: rationality and humanism as opposed to medieval superstition and brutality provide a sound basis for arguing that it is unlawful to compel anybody to contribute to the establishment of their own guilt. ${ }^{6}$ Grounds that are more practical for this position are the presumption of innocence, risk of false confessions, and the general need to protect the innocent from the inappropriate use of the coercive powers of the state. Moreover, it has been argued in the legal literature that the accused's duty to contribute to the investigation would impose such an overwhelming moral task that it would be unreasonable to require anybody to fulfil it. ${ }^{7}$ Thus, even if the legislator (for some reason) abolished the privilege and established a duty to self-incriminate, it most likely would not be applied in real life-or at least the costs of controlling this kind of duty would exceed the benefits. In other words, the duty to incriminate oneself would not only constitute a violation of human rights, but it would also be ineffective.

However, in my view, the moral premises mentioned above fail to provide a solution to the problem of active lying. While they clearly underpin the right to remain passive, they lend much less support to the right to give false statements. Consequently, there is a need to identify some other grounds for the right to lie. That is, unless we assume it is ultimately a matter of choice: do we want the privilege against self-incrimination to in-

$5 \quad$ The $50^{\text {th }}$ anniversary of the case Miranda v. Arizona, 3.8.4. U.S. 436 (1966) was a source of inspiration for even more academic writing on the privilege against self-incrimination. See, for example, Taylor, You Have the Right to Be Confused! Understanding Miranda After 50 Years, 36 Pace L. Rev. 158 (2015), available at http://digitalcommons.pace.edu/plr/vol36/iss1/5, describing 'the right to be confused' as a progeny of the Miranda case.

6 On the historical background of the privilege against self-incrimination (whether the roots lie in English common law or rather in the continental tradition based on Roman and canon law), see Helmholz, Origins of the Privilege against Self-Incrimination: The Role of the European Ius Commune, 65 New York University Law Review 962 (1990), available at https://chicagounbound. uchicago.edu/journal_articles/index.7.html, and Langbein, The Historical Origins of the Privilege Against Self-Incrimination at Common Law (1994). Faculty Scholarship Series. Paper 550, available at http://digitalcommons.law.yale.edu/fss_papers/550.

7 This has been stated in the Finnish legal literature by saying that 'the human nature is too weak' to sustain the duty to contribute in connection with self-related criminal investigations. See Hormia, Todistamiskielloista rikosprosessissa I. (Suomalaisen Lakimiesyhdistyksen julkaisuja, A-sarja N:o 125, 1978) pp. 175-176. 
clude both the right to silence and to active lying in non-criminal proceedings running concurrently with criminal investigations, or not?

\section{Finnish Case Law and Legislation Before Marttinen v. Finland}

In Finnish case law before 2009, it was settled by many judgments of the Supreme Court that the privilege against self-incrimination was nothing more than a principle governing preliminary investigations in criminal cases and trials in court (in both civil and criminal cases). Due to this position, bankruptcy and enforcement proceedings fell outside of the scope of the privilege. The core reason for this was that the debtor, when disclosing information in insolvency proceedings, was legally not suspected or accused of committing a crime. In case law, no attention was paid to the possibility of a concurrent criminal proceeding, nor to the fact that the obligation to disclose information in insolvency proceedings might lead-as it often did-to a result in which the debtor was forced to incriminate him/herself. ${ }^{8}$

By setting insolvency procedures aside from the scope of the privilege, debtors who refused to disclose the required information were convicted of fraud by a debtor, despite the fact that the required information concerned the same facts (same questions of evidence) that were investigated in the criminal proceeding pending concurrently with the enforcement proceedings or bankruptcy. ${ }^{9}$

Nor did the legislation of Finland help debtors who were struggling without protection against self-incrimination. In the Finnish Bankruptcy Act, ${ }^{10}$ there were no provisions regarding the privilege. With no exceptions, Chapter 4 Section 5 of the Bankruptcy Act obligated debtors to disclose to the estate administrator all the information regarding the assets of the estate and the claims in bankruptcy, as well as any other information nec-

8 Over the centuries, the differences between Finnish and American bankruptcy laws have been remarkable. The basic thinking on the privilege against self-incrimination in bankruptcy is one of the landmarks of these divergences. For the origins and the present state of the privilege in U.S. bankruptcy law, see Tarvin, The Privilege Against Self-Incrimination in Bankruptcy and the Plight of the Debtor, 44 Seton Hall L. Rev. (2014, Iss. 1, Article 2) pp. 47-105 (including appendixes), available at https://scholarship.shu.edu/shlr/vol44/iss1/2, stating on p. 53, 'There is no requirement that debtors be told about the privilege prior to filing or interrogation.

9 Judgment of the Finnish Supreme Court, Högsta Domstolen (hereinafter HD) 2009:27. See also the earlier precedents HD 2002:116, HD 2002:122 and HD 2003:13. The ruling HD 2009:80 will be observed in detail later in this article. The offences titled 'fraud by a debtor' and 'aggravated fraud by a debtor' are criminalised in the Criminal Code of Finland (19.12.1889/39 with later amendments), Chapter 39 Sections 2 and 3 (both 24.8.1990/769). 
essary for concluding the bankruptcy proceedings in an appropriate manner. ${ }^{11}$ The Finnish Enforcement Code, ${ }^{12}$ in turn, was amended by provisions concerning the privilege, but this amendment came too late to prevent the problems that finally led to the case of Marttinen v. Finland. Only four days before the ECtHR's judgment in the Marttinen case, the Finnish Supreme Court gave yet another ruling where it was confirmed, once again, that the privilege against self-incrimination did not protect a debtor in bankruptcy. ${ }^{13}$

\section{Direct Impact of Marttinen v. Finland on Finnish Case Law, Law Drafting and Legislation}

\subsection{The Reversal of the Prevailing Position of Case Law}

Right after the judgment of the ECtHR in the Marttinen case, it became clear that the traditional, prevailing position of Finnish case law had to be reversed. The prevailing position was, without a doubt, violating Article 6 of the Convention. However, the Supreme Court of Finland did not hesitate to do what was inevitable: Just six months after the judgement of the ECtHR, the Supreme Court in HD 2009:80 reversed its own ruling from HD 2009:27 concerning the aggravated debtor's fraud. It dismissed the charge and freed the accused from criminal liability on the grounds of the privilege against self-incrimination.

The legal justification for the reversal of the traditional stance was, primarily, the judgments of the ECtHR, not only in the case of Marttinen but also in general. At the national level, the Supreme Court applied Chapter 31 Section 8 of the Code of Judicial Procedure

11 The obligation of the debtor to contribute and to disclose information in insolvency procedures is a somewhat 'natural' and essential element of insolvency law, regardless of whether the aim of a particular procedure is liquidation or rehabilitation of the debtor in financial distress. The roots of this duty relate to the basic principles of debtor-creditor law, company law, general law of property and obligations, as well as to criminal law and the law of criminal procedure. Discussions of the honesty and loyalty of the debtor, of the avoidance of fraud and of the fiduciary nature of the debtor's duties have been wide, especially in universities in the United States. See e.g. Wu, Motivating Disclosure by a Debtor in Bankruptcy: The Bankruptcy Code, Intellectual Property, and Fiduciary Duties, 26 Yale J. on Reg. (2009) pp. 481-510, at 490-492, available at: http:// digitalcommons.law.yale.edu/yjreg/vol26/iss2/14. For the substantial requirements underlying the duty to disclose adequate information, see Gatto, Disclosure in Chapter 11 Reorganizations: The Pursuit of Consistency and Clarity, 70 Cornell L. Rev. 733 (1985) pp. 733-755, available at: http://scholarship.law.cornell.edu/clr/vol70/iss4/11 (evaluating also the changes to the process of disclosure statements in U.S. bankruptcy law before and after the Bankruptcy Reform Act of 1978).

12 Enforcement Code (Ulosottokaari, Utsökningsbalk) 15.6.2007/705.

$13 \quad$ HD 2009:27, given on 17 April 2009. 
(1.1.1734/4), according to which a final judgment in a criminal case may be reversed to the benefit of the defendant if the judgment is manifestly based on a misapplication of the law. By doing so, the Court made clear that the prevailing position of Finnish case law had for many years been based on a misapplication of the law.

\subsection{Legislative Options to Avoid Self-Incrimination in Concurrent Proceedings: The Silence Model and the Firewall Model}

After Marttinen v. Finland, and after the new position of national case law, the Finnish Government had to make a choice: whether to leave the privilege against self-incrimination to be governed by this new case law or to draft law reform. The government chose the latter by starting the draft work in the Ministry of Justice.

Legislative options to secure the privilege against self-incrimination in concurrent proceedings can be divided into two basic models. Let us call them the 'silence model' and the 'firewall model'. The former provides, simply enough, the right to remain silent in a concurrent procedure where questions of evidence are essentially the same as they are in a criminal case against the same person. The latter, in turn, means that there is no right to silence. Instead, all relevant information must be disclosed, but this information either shall be kept confidential or shall be excluded from the evidence that can be legally used in a criminal case. Both the confidentiality and prohibition of the use of evidence mean that the law provides a 'firewall' or a shield against violations to the privilege against self-incrimination.

According to the Enforcement Code of Finland, the safeguards against self-incrimination in the enforcement proceedings are governed by the firewall model. ${ }^{14}$ The enforcement authority (the bailiff) may not disclose any information that has, for an essential part, been received from the debtor if that information indicates that he or she has committed an offence outside the scope of the enforcement proceeding, and the disclosure of that information would render the debtor liable to prosecution. ${ }^{15}$ While this firewall protects debtors from self-incrimination, it also means the debtor enjoys no right to silence in enforcement proceedings. The firewall goes even further: the debtor is not allowed to give false statements in the enforcement procedure. Active lying or hiding of the relevant information may form the basis of conviction for fraud by a debtor. This means that the firewall model stipulated in the Enforcement Code of Finland only makes sense if the debtor is bound by the duties of: which the firewall model was adopted into Finnish law came too late to prevent the convicting judgement of the ECtHR in the Marttinen case.

15 This is stipulated in the Enforcement Code, Chapter 3 Section 73(1)(2). 
1) Disclosing the information asked by the bailiff, and;

2) Telling the truth.

The privilege against self-incrimination in the enforcement proceedings is guaranteed by obliging the bailiff (and the creditors) to hold the information in confidence and not to make use of it for any purposes of charging the debtor with criminal liability. Currently, under Finnish law, there is also a general prohibition against using information as evidence in cases where this use would violate the privilege against self-incrimination. ${ }^{16}$

The amendments enacted in 2013 to the Bankruptcy Act of Finland led to a completely different outcome compared to the Enforcement Code. ${ }^{17}$ Following these amendments, the law now provides for the debtor in bankruptcy the right to remain silent. If the debtor is suspected of an offence in the preliminary investigation, or if a charge of an offence is brought already, the debtor is not required to disclose to the estate administrator any information regarding the circumstances on which such a suspicion or charge is based. After a long and stony road towards ensuring the privilege against self-incrimination, the silence model is now in force in the Finnish law of bankruptcy. ${ }^{18}$

For the purposes of this article, the key question is whether the silence model stipulated in the Bankruptcy Act of Finland also grants the debtor the right to give false statements, that is, to lie. In the preamble to the amendment of the Bankruptcy Act, this alternative is clearly rejected. Although the new provision allows the debtor in bankruptcy proceedings to withhold information under circumstances that may contribute to the establishment of his or her guilt in a concurrent criminal case, it will not authorise the debtor to give false information to the estate administrator. Any information the debtor voluntarily discloses must be true, and false statements are criminalised as fraud by a debtor. $^{19}$

16 This general prohibition is stipulated in the Code of Judicial Procedure (1.1.1734 with later amendments), Chapter 17 Section 25(2) which was enacted as a part of the complete reform of the law of evidence (act of 12.6.2015/732).

17 Bankruptcy Act (20.2.2004/120) was reformed by the act of 31.1.2013/86.

18 See Bankruptcy Act, Chapter 4 Section 5a, which came into force on 1 March 2013.

19 See the Governmental Bill 86/2012 on proposed amendments to the Bankruptcy Act pp. 13 and 20. See also the Swedish version of the draft works for this reform RP 86/2012 rd (Regeringens proposition till riksdagen med förslag till lagar om ändring av konkurslagen samt av $24 \$ \mathrm{i}$ lagen om återvinning till konkursbo, p. 21): 'Även om bestämmelsen ger gäldenären rätt att låta bli att berätta om omständigheter som kan medverka till att hans eller hennes skuld utreds $i$ ett anhängigt brottmål, ger den inte konkursgäldenären rätt att ge boförvaltaren osanna uppgifter. Om gäldenären frivilligt lämnar de uppgifter som förutsätts $i$ konkurslagen, ska dessa uppgifter vara sanningsenliga.' As stated above in this article, this means de facto a duty to exercise the right to remain silent. 
As stated above, a debtor in the enforcement proceedings is required to disclose truthful information, while the debtor in bankruptcy has the right to remain silent. By considering this in terms of rational self-interest, it makes sense for the debtor to file for bankruptcy because it provides the right to remain silent. In my view, the present state of the law is unsatisfactory in terms of the system of insolvency procedures as a whole and regarding the legal protection of creditors. ${ }^{20}$

The compatibility of the firewall model with human rights has been tested both in the law-making process and later in the case law of Finland. After the Supreme Court precedent HD 2009:80, it was proposed by the Ministry of Justice that the firewall model also be included in the Bankruptcy Act by applying similar provisions and principles to those applied according to the Enforcement Code. ${ }^{21}$ In its opinion on the proposal, the Supreme Court tackled such an amendment, arguing that it was not consistent with Finland's obligations to human rights. Four years later, however, the firewall model was accepted by the Supreme Court in its precedent HD 2014:82. The argumentation in that precedent shows no reason for the change to the Supreme Court's position compared to its statement on the same question four years earlier.

Given the present state of Finnish law, it is interesting to look at further case law regarding the problem of false statements in non-criminal proceedings that are pending simultaneously with a pre-trial investigation or with a charge of a crime in court.

\section{Drawing the Line between Silence and False Statements}

\subsection{Starting Points}

As far as the preliminary investigation or the criminal procedure in court is concerned, any false statements made by the suspect or the accused in those proceedings will not lead to harmful consequences against him or her. After all, aside from the right to remain silent, the suspect and the accused are entitled to be heard and, if they choose to

20 In the discussion about the privilege against self-incrimination, it has been entirely ignored that among the creditors of an insolvent debtor, there might be and there often are natural persons. This is a fact, even though the majority of creditors are legal persons, i.e., credit institutions and insurance companies, for example. Natural persons, even in the capacity of a creditor, are entitled to claim for human rights and for the basic rights guaranteed in the Constitution of Finland (11.6.1999/731, Suomen perustuslaki, Finlands grundlag). In the context of insolvency proceedings, the protection of property (guaranteed in Section 15 of the Constitution of Finland) is of high importance for creditors, regardless of whether they are natural or legal persons.

21 The proposal was made by the Working Group on the Revision of the Bankruptcy Act (Ministry of Justice, Reports and opinions 73/2010, 30 September 2010). 
exercise this right, they are not obliged to tell the truth. ${ }^{22}$ The significance of the suspect's and the accused's own statements will then be decided as part of the free deliberation of evidence. ${ }^{23}$ While the issue is resolved case by case, the suspect and the accused are not bound by an obligation to be truthful, which may naturally affect the significance ascribed to his or her statements.

Consequently, the question of whether false statements are allowed relates to non-criminal proceedings in which the main purpose is not to determine anyone's guilt of a crime. Despite the different main purpose, those non-criminal proceedings are, however, closely connected to the allegation of a criminal offence because the facts (the questions of evidence) are essentially the same that are investigated in the concurrent criminal procedure. Examples of these proceedings have been observed earlier in this article (bankruptcy, the enforcement proceedings, official tax audit). Additionally, a classic case of the right to remain silent is applied in the testimony of a witness, which is addressed in Chapter 17 Section 18 of the Judicial Code of Finland. According to the wording of that section, 'Everyone has the right to refuse to testify' in self-incriminating situations. The reform of the Finnish law of evidence did not change the rule that by waiving the right to remain silent, the witness is automatically subject to the duty to tell the truth in the testimony. ${ }^{24}$

\subsection{Concurrent Proceedings, False Statements, and the Question of Criminal Liability}

In the aftermath of the Marttinen case, the question of the right to make false statements in concurrent, non-criminal proceedings was for the first time assessed by the Supreme Court with the precedent HD 2011:46, which concerned tax audits and tax fraud: ${ }^{25}$

At the same time as a pre-trial investigation was being conducted in respect of person A
for tax fraud, the Tax Administration carried out a tax audit in the company. The pros-
ecutor pressed charges for aggravated tax fraud on the grounds that A had given false

22 On the tension between the right of the accused to remain silent and the right to be heard in a criminal procedure, see Hupli, Syytetyn aktivoituminen käräjäoikeuden tuomion jälkeen (Lakimies 2011) pp. 227-247.

23 The judge's right and duty to a free deliberation of evidence is specifically expressed in Chapter 17 Section 1(2) of the Code of Judicial Procedure.

24 Chapter 17 Section 43(2) of the Code of Judicial Procedure (as reformed by the act of 12.6.2015/732). For the preparatory works of this section, see RP 46/2014 rd (Regeringens proposition till riksdagen med förslag till revidering av 17 kap. i rättegångsbalken och av den lagstiftning om bevisning i de allmänna domstolarna som har samband med den) pp. 104-105 (stating that the substance of the proposed section is identical with the prevailing law).

25 The title text of the precedent is here translated from Finnish to English by the author of this article. 
information in the course of the tax audit, thereby causing or attempting to cause the business income tax to be set too low. The pre-trial investigation and tax audit targeted the same actions taken by A. In its reasoning, the Supreme Court held that A's actions in connection with the tax audit could not be deemed punishable for reasons related to the privilege against self-incrimination. The charge for aggravated tax fraud was dismissed.

In its reasoning, the Supreme Court took the position that the disclosure of false information is tantamount, i.e., equivalent, to exercising the right to silence. In this regard, the Supreme Court relies on the same wording as the ECtHR in Marttinen v. Finland by stating that any punishment for the disclosure of false information would extinguish the very essence of the suspect's right to silence or not to contribute to the establishment of his own guilt.

The English version of the same passage in the ECtHR's judgment (para. 75) reads as follows: ${ }^{26}$

The Court, accordingly, finds that the concerns for the effective functioning of the debt recovery procedure relied on by the Finnish Government cannot justify a provision which extinguishes the very essence of the applicant's rights to silence and against self-incrimination guaranteed by the Convention.

The Supreme Court's finding in HD 2011:46 seems to indicate that the legal prohibition against providing false information in non-criminal proceedings actually extinguishes the very essence of the right to remain passive and silent. Logically, this would mean that silence and lying are equated. In my view, there are no grounds for such equating. This is not to say that there should be an absolute duty to tell the truth in every case. What it does mean is that equating silence with false statements is not a convincing reason to explain and justify the right to provide false information. In my view, there is a need to find a more convincing justification for that.

One might ask for a more detailed analysis of the need for a more convincing justification: why is it unconvincing to equate a protection of silence with a protection of lying? First, for all practical and theoretical purposes, it is a completely different thing to exercise the right to remain silent than to waive it. The difference can be illustrated by the circumstances of Marttinen v. Finland: the accused (Mr Marttinen) exercised his right to remain silent in an enforcement inquiry, and, as the ECtHR stated, the threat of a fine ordered by the bailiff put pressure on him to waive this right. The imposition of a 
conditional fine in the enforcement inquiry thus violated Article 6 of the Convention. In contrast, the requirement that no false statements should be made in an enforcement inquiry (or in bankruptcy, in a tax audit, etc.) does not constitute pressure to waive the right to silence. Rather, the duty to avoid false statements urges the exercising of the right to remain silent. ${ }^{27}$

Precedent HD 2011:46 was given only two years after the ECtHR's judgment in the Marttinen case. The analysis described above in this article shows that in HD 2011:46 the Supreme Court of Finland reasoned that exercising the right to remain silent must be equated with waiving the same right. As the years have gone by, and as the initial shock from the ECtHR's ruling has passed, the Supreme Court of Finland has changed its view in this respect by giving two remarkable precedents. Both of them concern the testimony (or the hearing of a party) in civil disputes that were pending concurrently with a criminal case involving the same questions of evidence. The first is precedent HD 2015:6, where the question was whether the two accused persons had committed themselves to a false statement in court by lying in a civil case. The facts of HD 2015:6 were as follows: ${ }^{28}$

Person $A$ and person $B$ had been heard in the district court as witnesses in a dispute that involved circumstances for which charges had been brought against both. Subsequently, the prosecutor demanded that $A$ and $B$ be punished for giving false statements in court because of what they had told the district court without resorting to the right to refuse to testify.

In its judgment, the Supreme Court concluded that neither A nor B's privilege against self-incrimination had been violated, and the restrictive provision of false statements was not to be applied. A and B were convicted of making a false statement in court. ${ }^{29}$

The second precedent to be analysed here is HD 2017:78:30

27 As mentioned above, the Enforcement Code (705/2007) has now been amended by the firewall provisions that provide for the debtor no right to remain silent, but rather stipulate that any information given in the enforcement inquiry shall be confidential or shall be excluded from the legal evidence in a criminal case concerning the same facts (thus protecting the debtor in cases where the firewall has 'leaked'). This law reform came into force too late for the Marttinen case.

28 The title text of the precedent is here translated from Finnish to English by the author of this article.

29 The restrictive provision (the 'limitation rule') concerning false statements is stipulated in the Criminal Code (19.12.1889/39), Chapter 15 Section 13. This provision, especially the general principle expressed therein, will be observed later in this article.

30 The title text of the precedent is here translated from Finnish to English by the author of this article. 
Person A had been personally heard in the district court in two disputes, both concerning the recovery to the bankruptcy estate. Before these hearings A had been heard as a suspect for a crime (the offences by a debtor), the circumstances of which were connected to the two civil cases concerning the recovery to the bankruptcy estate. A was then charged for a fraud and aggravated fraud on the grounds that by telling against the truth in the said civil disputes in order to obtain unlawful financial benefit, A had mislead the district court and by that way caused that the claims of the bankruptcy estate had been dismissed, for which the estate had suffered damage. For reasons expressed in the Supreme Court's decision, A's privilege against self-incrimination had not been insulted. The alleged violation of the privilege was not a legal ground for dismissing the charges of fraud and aggravated fraud.

Naturally, it is of great interest for the purposes of this article to explore the grounds on which the conclusions of these two precedents differ from the original position that the Supreme Court confirmed in its first ruling (HD 2011:46) in the aftermath of the Marttinen case. After all, the basic setting in all of these three cases was identical: criminal proceedings were pending concurrently with non-criminal procedures, and the same questions of evidence were investigated simultaneously. Additionally, in all of these cases there was no doubt that the accused had the right to remain silent, but this right was waived by all of the accused persons. In the first precedent, silence was equated with false statements, but in the later ones, false statements placed criminal liability on the accused. The question of interest for academics is how this disparity should be assessed.

To start the assessment, the interpretation of the law should depend on the principle of treating similar cases similarly. From this point, I find it problematic to interpret the privilege against self-incrimination on a case by case basis or in a way that creates remarkable divergences between the different types of legal proceedings. Although the aims vary between the procedures, it cannot be acceptable to allow false statements in one kind of proceeding and deny them in another. Divergences in the governance of the privilege against self-incrimination would require clear provisions stipulated in the law (the Act of Parliament).

From the reasoning of the Supreme Court in HD 2015:6 can be seen the line of thinking that the purpose of hearing someone personally is in some way different in context of a tax audit than it is in a court procedure. This conclusion might be drawn from the Supreme Court's reasoning that hearing a witness (or a party) in a trial aims to determine the truth in a particular case. However, this explains nothing about the problem we are considering here. When someone is heard in a tax audit, the aim of the hearing is to find the truth about the grounds of the tax liability. Therefore, there is no difference in the purpose of the hearing compared to the hearing in a trial before the court. The purpose of any hearing is to find the truth. 
This article is written to propose two important principles that might (in my view should) be established as foremost when considering whether the privilege against self-incrimination only includes the right to remain silent or if it provides the right to give false statements as well. The first of these principles is the sufficiency (or insufficiency) of silence. According to this principle, false statements would not constitute a crime when the silence alone would not have been sufficient (effective enough) to protect the suspect or the accused from self-incrimination. In these types of cases, waiving the right to remain silent has been necessary to achieve the goal of the privilege. Vice versa, false statements would constitute a crime when they would not have been necessary to achieve that goal, i.e., exercising the right to remain silent would have been sufficient (effective enough) to protect the privilege against self-incrimination.

The second principle concerns the motives of the suspect or the accused in waiving the right to remain silent. According to this principle, if the motives for the waiver have not only been to avoid the inappropriate use of coercive power, then providing false statements should constitute a crime. In these kinds of cases, the suspect or the accused is telling against the truth to achieve something that is not protected by the privilege against self-incrimination.

The legislative background for both of the principles described above can be found from the Criminal Code of Finland (19.12.1889/39). First, regarding the principle of the sufficiency of silence, the provisions on false statement do not apply if it has been 'impossible to keep to the truth without the danger that the person heard himself or herself becoming liable for an offence or a comparable unlawful act. ${ }^{31}$ Although this restrictive provision was originally enacted in the Criminal Code only for offences against the administration of justice, there can hardly be any reason to deny that the same principle should be applied by analogy in any situation where the question is about the lawfulness or unlawfulness of false statements. The moral ground is the same as it is for the privilege against self-incrimination itself: the suspect or the accused is subject to the criminal investigations regarding the facts that might prove him or her guilty of a crime, and simultaneously, he or she has the duty to reveal those facts in a concurrent non-criminal proceeding. Applying this principle by analogy would at least be a more convincing way to deal with these problems compared to awkwardly identifying false statements with silence.

The second principle mentioned above, concerning the motives of the accused in self-incriminating situations, can also be traced to the very heart of the privilege against self-incrimination. Although the suspect and the accused need protection against the inappropriate use of coercive public power, it is not unusual that false statements affect private persons or entities as well. This was exactly the case in HD 2017:78. The accused

31 This is the restrictive provision (the 'limitation rule') in the Criminal Code, Chapter $15 \$ 13$, mentioned above in this article and referred to by the Supreme Court in HD 2015:6. 
had appointed himself to be heard in two civil disputes that were pending concurrently with the criminal investigations against him, concerning the same questions of evidence. By appointing himself to be heard in civil cases, the accused did not merely aim to enjoy the privilege against self-incrimination (i.e., the protection against the inappropriate use of coercive power). The accused's motives to give false statements in civil disputes were, in fact, to win those cases and therefore to obtain unlawful financial benefits detrimental to the creditors of the bankrupt debtor. In addition, nothing indicated that it would have been impossible for the accused to remain silent or to keep to the truth without endangering his privilege against self-incrimination. For these reasons, the accused had no right to provide false statements in civil disputes. Instead, he should have exercised the lawful safeguards, i.e., to remain silent.

\section{Conclusions and a Look to the Future}

Since precedent HD 2009:80, progress has clearly been made in Finnish law (in legislation and case law) regarding the privilege against self-incrimination. Even so, there is no reason for any kind of complacency, as it remains somewhat unclear when the privilege against self-incrimination simply means the right to remain silent, and when it also includes the right to provide false statements.

The reasoning and the outcome of the precedent HD 2011:46 mean that silence is equated with false statements. This means, in fact, that both the exercising and the waiving of the same right-the right to remain silent-were deemed the same thing. On the foregoing grounds, such equating is unconvincing. Conceivably, the question of the right to give false statements may in the future end up before the ECtHR.

The content of the privilege against self-incrimination has evolved both in direct response, and subsequently to the ECtHR's judgment in Marttinen v. Finland. The moral and legal notion of the problem of false statements is now clearer than it was a decade ago. In this article, I have tried to justify two main principles that might or even should be applied to provide guidance for moral and legal thinking when the question is about the lawfulness or unlawfulness of false statements. In cases where silence as such does not amount to securing the privilege against self-incrimination, waiving the right to remain silent (i.e., choosing to provide false statements) is defensible in most situations. This should be considered regarding the criminal liability of fraud and tax fraud, fraud by a debtor, offences against the administration of justice or any other offences where the accused's moral ability to tell the truth is challenged. Accordingly, in cases where false statements would not have been necessary to avoid self-incrimination, providing false statements would result in a criminal liability (subject to the provision in the Criminal Code, or to a special provision somewhere else in the legislation). The motives of the ac- 
cused are in these latter kinds of cases something other than simply to ensure protection from the inappropriate use of coercive public power.

Essentially, the privilege against self-incrimination is about the right to remain silent while any official investigation of an alleged crime is pending. Active lying in concurrent non-criminal proceedings tests the limits of this privilege profoundly and, unfortunately, might challenge the very legitimacy of it. At worst, an absolutely unlimited right to provide false statements opens the gates to a miscarriage of justice detrimental to other private persons or entities. When this is the case, we are not only dealing with the protection of an individual against the punitive powers of the state, but also with the justified expectations between individuals. ${ }^{32}$

The aim of the discussion in this article is not to criticise the privilege against self-incrimination as such but to analyse its ambiguities. As we already know from legal praxis of the ECtHR and of the national courts, a more detailed content of the privilege against self-incrimination leads to problems of interpretation. However, this is the price to be paid for this privilege as an integral part of a fair trial. The peculiar discrepancies in the legislation of Finland (fundamental differences between the Enforcement Code and the Bankruptcy Act) are likely to aggravate the problems of interpretation. It would be possible to alleviate them by amending the law, but this is of course a subject for a wider debate-and for a new article someday in the future.

32 This principle is illustrated in the preparatory works for the amendments to the Criminal Code of Finland (39/1889, presently as amended by the act of $12.6 .2015 / 735)$, stating that the culpability of a false statement depends on the question of whether it has caused loss or damage to anyone. See RP 6/1997 rd (Regeringens proposition till Riksdagen med förslag till revidering av stadgandena om brott mot rättskipning, myndigheter och allmän ordning samt om sexualbrott) p. 47, where it is stated in Swedish as follows: 'Klandervärdheten minskar särskilt $i$ sådana fall då ingen till följd av de felaktiga uppgifterna har lidit någon rättsförlust eller annan skada.). According to the Criminal Code of Finland, Chapter 15 Section 3(1), considerable damage caused by a false statement is one of the qualifications for an aggravated false statement in court. 